\title{
Biochemical profile of human infant cerebrospinal fluid in intraventricular hemorrhage and post-hemorrhagic hydrocephalus of prematurity
}

Ayodamola Otun ${ }^{1 *} \mathbb{0}$, Diego M. Morales ${ }^{1}$, Maria Garcia-Bonilla', Seth Goldberg ${ }^{2}$, Leandro Castaneyra-Ruiz ${ }^{5}$, Yan Yan ${ }^{3}$, Albert M. Isaacs ${ }^{4}$, Jennifer M. Strahle', James P. McAllister II and David D. Limbrick Jr ${ }^{1}$

\begin{abstract}
Background: Intraventricular hemorrhage (IVH) and post-hemorrhagic hydrocephalus (PHH) have a complex pathophysiology involving inflammatory response, ventricular zone and cell-cell junction disruption, and choroidplexus (ChP) hypersecretion. Increased cerebrospinal fluid (CSF) cytokines, extracellular matrix proteins, and blood metabolites have been noted in IVH/PHH, but osmolality and electrolyte disturbances have not been evaluated in human infants with these conditions. We hypothesized that CSF total protein, osmolality, electrolytes, and immune cells increase in $\mathrm{PHH}$.
\end{abstract}

Methods: CSF samples were obtained from lumbar punctures of control infants and infants with IVH prior to the development of $\mathrm{PHH}$ and any neurosurgical intervention. Osmolality, total protein, and electrolytes were measured in 52 infants (18 controls, 10 low grade (LG) IVH, 13 high grade (HG) IVH, and $11 \mathrm{PHH}$ ). Serum electrolyte concentrations, and CSF and serum cell counts within 1-day of clinical sampling were obtained from clinical charts. Frontal occipital horn ratio (FOR) was measured for estimating the degree of ventriculomegaly. Dunn or Tukey's post-test ANOVA analysis were used for pair-wise comparisons.

Results: CSF osmolality, sodium, potassium, and chloride were elevated in $\mathrm{PHH}$ compared to control $(p=0.012-<0.0001)$, LGIVH $(p=0.023-<0.0001)$, and HGIVH $(p=0.015-0.0003)$, while magnesium and calcium levels were higher compared to control $(p=0.031)$ and LGIVH $(p=0.041)$. CSF total protein was higher in both HGIVH and PHH compared to control ( $p=0.0009$ and 0.0006 respectively) and LGIVH ( $p=0.034$ and 0.028 respectively). These differences were not reflected in serum electrolyte concentrations nor calculated osmolality across the groups. However, quantitatively, CSF sodium and chloride contributed $86 \%$ of CSF osmolality change between control and PHH; and CSF osmolality positively correlated with CSF sodium ( $r, p=0.55,0.0015)$, potassium $(r, p=0.51,0.0041)$, chloride $(r, p=0.60,0.0004)$, but not total protein across the entire patient cohort. CSF total cells $(p=0.012)$, total nucleated cells $(p=0.0005)$, and percent monocyte $(p=0.016)$ were elevated in PHH compared to control. Serum white blood cell count increased in PHH compared to control $(p=0.042)$ but there were no differences in serum cell

*Correspondence: aotun@wustl.edu

1 Department of Neurosurgery, Washington University in St. Louis School of Medicine, St. Louis, MO 63110, USA

Full list of author information is available at the end of the article

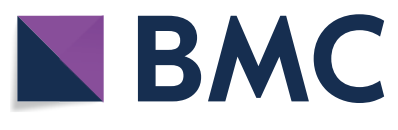
permits use, sharing, adaptation, distribution and reproduction in any medium or format, as long as you give appropriate credit to the original author(s) and the source, provide a link to the Creative Commons licence, and indicate if changes were made. The images or other third party material in this article are included in the article's Creative Commons licence, unless indicated otherwise in a credit line to the material. If material is not included in the article's Creative Commons licence and your intended use is not permitted by statutory regulation or exceeds the permitted use, you will need to obtain permission directly from the copyright holder. To view a copy of this licence, visit http://creativecommons.org/licenses/by/4.0/. The Creative Commons Public Domain Dedication waiver (http://creativeco mmons.org/publicdomain/zero/1.0/) applies to the data made available in this article, unless otherwise stated in a credit line to the data. 
differential across groups. CSF total nucleated cells also positively correlated with CSF osmolality, sodium, potassium, and total protein $(p=0.025-0.0008)$ in the whole cohort.

Conclusions: CSF osmolality increased in $\mathrm{PHH}$, largely driven by electrolyte changes rather than protein levels. However, serum electrolytes levels were unchanged across groups. CSF osmolality and electrolyte changes were correlated with CSF total nucleated cells which were also increased in $\mathrm{PHH}$, further suggesting $\mathrm{PHH}$ is a neuro-inflammatory condition.

Keywords: Post-hemorrhagic hydrocephalus (PHH), Intraventricular hemorrhage (IVH), CSF osmolality, CSF electrolytes, Cerebrospinal fluid (CSF)

\section{Introduction}

High grade intraventricular hemorrhage (HGIVH), defined as IVH with blood filling more than $50 \%$ of the ventricular volume (Papile grades III-IV) [1], affects nearly $20 \%$ of preterm infants with post-menstrual age $<28$ weeks $[2,3]$ and is associated with post-hemorrhagic hydrocephalus $(\mathrm{PHH})$ in $25-50 \%$ of cases [3, 4]. HGIVH carries a risk of substantial neurological morbidity, but outcomes in PHH are among the worst in newborn medicine, with up to $85 \%$ of infants developing neurodevelopmental delay, visual impairment, cerebral palsy, deafness, or some combination of these [3, 5-7]. The pathophysiology of disability in HGIVH and $\mathrm{PHH}$ remain to be elucidated $[8,9]$.

$\mathrm{PHH}$ is a complex condition that involves neuroinflammation [8], alterations in ventricular zone (VZ) junctional biology [10-14], and choroid plexus (ChP) hypersecretion [15], among other processes. CSF studies of human infants with PHH $[2,4,16,17]$ have shown elevated inflammatory markers (chemokines and cytokines) [18-24]; mediators of neurodevelopment [25], extracellular matrix proteins $[2,7,25,26]$; blood-associated proteins and metabolites (hemoglobin, ferritin) [6, 27-29]; proteins involved in coagulation (fibrin and fibrin degradation products)[30,31]; and cell junction proteins $[2,7]$. However, only a limited number of studies have examined the biochemical profile of CSF in other forms of hydrocephalus [32,33], and no studies have reported these in PHH in human preterm infants to date. CSF osmolality and electrolyte concentration changes have been shown in diabetes ketoacidosis, febrile children, and a constellation of neurological diagnoses such as polyneuropathy, multiple sclerosis, amyotrophic lateral sclerosis, etc. [34-37]. Notably, CSF studies from animal models of hydrocephalus have implicated CSF osmolality in the development of ventriculomegaly [38, 39].

We hypothesized that $\mathrm{PHH}$ in human preterm infants is associated with alterations in the biochemical profile of CSF, including CSF electrolytes, total protein, and osmolality. To examine this hypothesis, we measured each of CSF osmolality, protein levels, and electrolyte concentrations in lumbar CSF and serum obtained from human infants with no known neurological injury, IVH (grades I/II and III/IV), and PHH. PHH was associated with increased CSF protein, osmolality, and specific electrolytes likely to impact osmotic and oncotic pressure. These findings provide novel insights into the putative pathophysiology of ventriculomegaly in $\mathrm{PHH}$. To our knowledge, this is the first study quantifying the biochemical profile of CSF in human infants with $\mathrm{PHH}$.

\section{Materials and methods \\ Research subjects and study design}

We retrospectively analyzed human CSF prospectively collected at Washington University/St. Louis Children's Hospital between November 2009 and December 2017. Included were infants born at post-menstrual age (PMA) $<34$ weeks with birth weight $<2000 \mathrm{~g}$ who underwent lumbar puncture (LP) in the St. Louis Children's Hospital (SLCH) Neonatal Intensive Care Unit (NICU) as a part of routine care. Neonates with no known neurologic disease who underwent a LP for sepsis evaluation where the evaluation and all cultures were negative were included as controls. Papile grading scale [1, 40] was used by a neuroradiologist to assign IVH grade. Neonates diagnosed with IVH grade I and II were included as low grade IVH (LGIVH) and IVH III-IV as high grade IVH (HGIVH). PHH was defined based on the Hydrocephalus Clinical Research Network (HCRN) guidelines[41] including infants with frontal occipital horn ratio $(F O R) \geq 0.55$ who required surgical treatment. $\mathrm{PHH}$ determination was also confirmed by an attending pediatric neurosurgeon (D.D.L., J.M.S.).

All CSF samples were acquired via standard LP and serum samples were acquired via routine clinical venipuncture $\mathrm{PHH}$ patients underwent temporizing neurosurgical treatment with a ventricular reservoir followed by permanent treatment with a CSF shunt, or, in some cases, endoscopic third ventriculostomy with choroid plexus cauterization. LP in IVH and PHH group was performed after the occurrence of IVH but prior to $\mathrm{PHH}$ diagnosis and any neurosurgical intervention.

All protocols and procedures were approved by the Washington University Human Research Protection 
Office and Institutional Review Board with a waiver of written informed consent (HRPO\# 201203126).

\section{Comorbidities}

The general health status of the neonates was assessed with the clinical risk index for babies minus temperature (CRIB II - T) [42] and a modified version of complex chronic conditions (CCC) [43]. The CRIB II-T score is a validated score that assesses initial mortality risk and illness severity within $1 \mathrm{~h}$ of admission [44, 45]. It uses the birth weight, sex, gestational age, and base excess to provide a score ranging from 1 to 27 . The CCC is a list of chronic conditions relevant to the pediatric population organized into categories. The modified CCC which redefines the neuromuscular category to exclude hydrocephalus has been used in many studies of hydrocephalus [46-49]. We also reported neonatal abstinence syndrome (NAS) and infection (chorioamnionitis, $\mathrm{n}=2$; congenital syphilis, $\mathrm{n}=1$; osteomyelitis, $\mathrm{n}=1$ ) to describe the current comorbidities particularly relevant to the cohort of patients included in this study more robustly.

\section{Specimen collection and processing}

CSF samples were collected by the NICU clinical team at SLCH using standard, sterile procedures for LP. CSF samples were sent to the SLCH clinical laboratory for clinically indicated microbiological culture (5-day sutveillance) and laboratory evaluation. Excess CSF or "saved" CSF samples were centrifuged at $1000 \mathrm{~g}$ for six minutes and the supernatant aliquoted, frozen $-20^{\circ} \mathrm{C}$ for 3 months before transfer to the Washington University Neonatal CSF Repository for freezing and storage at $-80^{\circ} \mathrm{C}$ until the time of experimental analysis, as described previously $[26,50]$. CSF cell count, and serum electrolyte, cell count, and differential analysis were obtained from the electronic medical record. Only serum samples within 1 day of the CSF sample collection were included in the study analysis.

\section{Osmolality, protein, and electrolyte measurements}

Osmolality was measured using the VAPRO vapor pressure osmometer (Wescor 5520), as described previously for analysis of CSF and other biofluids [51-53]. The osmometer was stored in a dry room with stable temperature. The instrument was calibrated prior to each use with a standard solution of $290 \mathrm{mmol} / \mathrm{L}$, with an error range of $\pm 3 \mathrm{mmol} / \mathrm{L}$. Following the manufacturer's recommendation based on expected variation, two readings were obtained for each sample, with a third obtained if the difference between the two initial readings was $>5 \mathrm{mmol} / \mathrm{L}$. The mean of the readings was recorded and used in the analysis. All samples were stored at $-80^{\circ} \mathrm{C}$ before use and at $0{ }^{\circ} \mathrm{C}$ in between readings.
CSF electrolyte (sodium, potassium, chloride, bicarbonate, glucose, magnesium, and calcium) measurements were performed in the Washington University core clinical laboratory for clinical studies after instrument validation using artificial CSF $(10 \mathrm{mM}$ glucose, $3.0 \mathrm{mM} \mathrm{KCl}$, $1.2 \mathrm{mM} \mathrm{KH} 2 \mathrm{PO} 4,2 \mathrm{mM} \mathrm{MgCl} 2,2.6 \mathrm{mM} \mathrm{CaCl} 2,124 \mathrm{mM}$ $\mathrm{NaCl}$, and $26 \mathrm{mM} \mathrm{NaHCO} 3$, see Additional file 1 for full description) to ensure reproducibility, linearity, and accuracy. All electrolyte assays were performed on a Roche Cobas c501 module of a Roche Cobas 6000 platform. Sodium, potassium, and chloride assays utilized an ionselective electrode, and their concentrations were determined by the Nernst equation. Magnesium assay was based on a colorimetric endpoint using reaction with xylidyl blue, while calcium assay was based on a complex of 5-nitro-5'-methyl-5-(1,2-bis(0-aminophenoxy)ethan$\mathrm{N}, \mathrm{N}, \mathrm{N}^{\prime} \mathrm{N}^{\prime}$-tetraacetic acid. Glucose was measured using the hexokinase coupled-enzyme assay method, while bicarbonate measurement was based on a phosphoenolpyruvate carboxylase/malate dehydrogenase coupled enzyme assay. Total protein was measured using the Pierce Bicinchoninic Acid protein assay kit (Thermo-scientific). The assay was run following the manufacturer's manual [2].

\section{Statistical analysis}

Mean and standard deviation were calculated for each experimental group for each variable measured. All statistical analysis were performed on GraphPad Prism 9 and statistical significance was set at an alpha level $<0.05$. Normality tests (Shapiro-Wilk) were performed and, if the data were normally distributed, ANOVA with Tukey post-test analyses were conducted. Otherwise, KruskalWallis ANOVA with Dunn's post-test analyses were performed for non-parametric data. Pearson or Spearman correlation test were also performed based on normality test result.

\section{Results}

\section{Patient characteristics}

A total of 52 patients were included in this study: 18 Control, $10 \mathrm{LGIVH}, 13 \mathrm{HGIVH}$, and $11 \mathrm{PHH}$ infants. There was a higher percentage of males in all groups (Table 1). There was no statistically significant difference between the PMA of the PHH subjects $(27.6 \pm 3.1$ weeks $)$ compared to control (PMA 31.1 $\pm 2.9 ; \mathrm{p}=0.068$ ), LGIVH (PMA 28.2 $\pm 2.8 ; \mathrm{p}>0.99$ ), or HGIVH (PMA 26.2 \pm 2.7 ; $\mathrm{p}>0.99)$. However, HGIVH infants were younger than control $(\mathrm{p}=0.0005)$. Crib II $-\mathrm{T}$ score was similar between PHH $(8.7 \pm 4.2)$ and control (CRIB II-T score $4.6 \pm 4 ; \mathrm{p}=0.15)$ but higher in HGIVH (CRIB II-T score $10.7 \pm 3.9)$ compared to control $(\mathrm{p}=0.0076)$. The CCC score was similar across the groups $(\mathrm{p}=0.39)$. The most 
Table 1 Summary of patient characteristics

\begin{tabular}{|c|c|c|c|c|c|}
\hline & Control $(\mathrm{N}=18)$ & $\operatorname{LGIVH}(\mathrm{N}=10)$ & $\operatorname{HGIVH}(\mathrm{N}=13)$ & $\mathrm{PHH}(\mathrm{N}=11)$ & $P$ value \\
\hline \multicolumn{6}{|l|}{ Sex } \\
\hline Male & $13(72.2)$ & $6(60.0)$ & $12(92.3)$ & $9(81.8)$ & \\
\hline Female & $5(27.8)$ & $4(40.0)$ & $1(7.7)$ & $2(18.2)$ & \\
\hline PMA birth (weeks) & $31.1 \pm 2.9$ & $28.2 \pm 2.8$ & $26.2 \pm 2.7$ & $27.6 \pm 3.1$ & $\begin{array}{l}0.0009 \\
\text { control vs HGIVH }(0.0005)\end{array}$ \\
\hline Birth Weight (g) & $1388.0 \pm 395.5$ & $1453.0 \pm 752.8$ & $986.2 \pm 396.2$ & $1041.1 \pm 260.9$ & $\begin{array}{l}0.037 \\
\text { control vs HGIVH (0.032) }\end{array}$ \\
\hline CRIB \|-T Score & $4.6 \pm 4.5$ & $6.9 \pm 4.7$ & $10.7 \pm 3.9$ & $8.7 \pm 4.2$ & $\begin{array}{l}0.012 \\
\text { control vs HGIVH (0.0076) }\end{array}$ \\
\hline Complex Chronic Conditions & $0.8 \pm 0.8$ & $1.0 \pm 0.7$ & $0.8 \pm 1.2$ & $1.4 \pm 1.1$ & 0.39 \\
\hline None & $9(50.0)$ & $2(20.0)$ & $7(53.8)$ & $3(27.3)$ & \\
\hline $1-2$ & $9(50.0)$ & $8(80.0)$ & $5(38.5)$ & $6(54.5)$ & \\
\hline $3-4$ & 0 & 0 & $1(7.7)$ & $2(18.2)$ & \\
\hline$>4$ & 0 & 0 & 0 & 0 & \\
\hline Respiratory & 6 & $4(40.0)$ & $4(30.8)$ & $7(63.6)$ & \\
\hline Cardiovascular & $3(16.7)$ & 0 & $2(15.4)$ & $4(36.4)$ & \\
\hline Neuromuscular & $2(11.1)$ & 0 & 0 & 0 & \\
\hline Ophthalmologic & $1(5.6)$ & $1(10.0)$ & $1(7.7)$ & 0 & \\
\hline Gastrointestinal & 0 & 0 & $2(15.4)$ & $1(9.1)$ & \\
\hline Infectious & 0 & $3(30.0)$ & 0 & 0 & \\
\hline Hematologic & $1(5.6)$ & 0 & 0 & 0 & \\
\hline NAS & $1(5.6)$ & $2(20.0)$ & 0 & 0 & \\
\hline FOR measurement & $0.35 \pm 0.04$ & $0.41 \pm 0.07$ & $0.49 \pm 0.06$ & $0.65 \pm 0.03$ & $\begin{array}{l}<0.0001 \\
\text { Control vs HGIVH }(0.0003) \text { and } \mathrm{PHH}(<0.0001) ; \\
\text { LGIVH vs HGIVH }(0.034) \text { and } \mathrm{PHH}(<0.0001) ; \\
\text { HGIVH vs PHH }(<0.0001)\end{array}$ \\
\hline
\end{tabular}

Values are reported as N (column \%) or mean \pm standard deviation. In the "P value' column, ANOVA summary p-value was recorded on the top row while significant pairwise post-test $P$ value were recorded on the bottom row. All pairwise comparisons were analyzed based on Dunn's or Tukey's post-test ANOVA depending on the distribution of the data (normal distribution or not). N, sample size; PMA, post-menstrual age; NAS, neonatal abstinence syndrome; FOR, frontal-occipital horn ratio

common category of comorbid condition in the entire cohort was respiratory followed by cardiovascular. FOR was higher in $\mathrm{PHH}$ compared to control $(\mathrm{p}<0.0001)$, LGIVH $(\mathrm{p}<0.0001)$, and HGIVH $(\mathrm{p}<0.0001)$. FOR was also higher in HGIVH compared to LGIVH $(p=0.034)$ and control $(\mathrm{p}=0.0003)$.

\section{CSF, serum culture and cell counts}

CSF and serum samples from all patients included in this study were cultured for five days and no growth of any micro-organism was noted. Compared to control, CSF total cells $(p=0.012)$, total nucleated cells $(p=0.0005)$, and percent monocytes $(\mathrm{p}=0.016)$ were higher in $\mathrm{PHH}$ (Table 2). Total nucleated cells $(\mathrm{p}=0.0079)$ and percent lymphocyte $(\mathrm{p}=0.043)$ were elevated in HGIVH compared to control. Comparing LGIVH to HGIVH and $\mathrm{PHH}$, total nucleated cells were also elevated in both HGIVH $(p=0.011)$ and PHH $(p=0.0010)$. There were no changes in percent neutrophils $(\mathrm{p}=0.24)$ and macrophages $(p=0.23)$ in the CSF across all groups. In the serum, on the other hand, only total white blood cell
(WBC) count was increased in PHH compared to control $(\mathrm{p}=0.042)$ and no changes in the relative distribution of the different serum white blood cell types. Serum platelet was higher in HGIVH compared to control $(\mathrm{p}=0.030)$, but no other differences were observed across groups.

\section{CSF osmolality, total protein, and glucose}

CSF osmolality was elevated in $\mathrm{PHH}$ compared to all other groups. CSF osmolality in the control, LGIVH, HGIVH, and PHH group were 280.5 (15.6); 270.5 (30.0); 262.0 (73.0); and 323.5 (60.7) mmol/L, (median (Interquartile range $[\mathrm{IQR}])$ ) respectively (Fig. 1). There was a $44.2 \mathrm{mmol} / \mathrm{L}$ absolute increase in mean osmolality in $\mathrm{PHH}$ CSF compared to control. Total protein was elevated in both HGIVH (median $174.3 \mathrm{mg} / \mathrm{dL}$ with IQR of 126.6) and $\mathrm{PHH}$ (median $187.5 \mathrm{mg} / \mathrm{dL}$ with IQR of 120.3) CSF relative to control (median $81.3 \mathrm{mg} / \mathrm{dL}$ with IQR of 76.9) and LGIVH (median $107.8 \mathrm{mg} / \mathrm{dL}$ with IQR of 61.5). CSF glucose was significantly lower in $\mathrm{PHH}$ (median $25.5 \mathrm{mg} / \mathrm{dL}$ with IQR of 28.7) compared to control (median $49.0 \mathrm{mg} / \mathrm{dL}$ with IQR of 9.5), LGIVH 
Table 2 Serum and CSF cellularity

\begin{tabular}{|c|c|c|c|c|c|}
\hline & Control $(\mathrm{N}=18)$ & LGIVH $(N=10)$ & HGIVH $(\mathrm{N}=13)$ & $\mathrm{PHH}(\mathrm{N}=11)$ & P value \\
\hline \multicolumn{6}{|l|}{ CSF } \\
\hline Total cells (cells/mcl) & $1711 \pm 4305$ & $452.7 \pm 596.1$ & $12,572 \pm 24,771$ & $39,788 \pm 70,835$ & $\begin{array}{l}0.014 \\
\text { Control vs PHH (0.012) }\end{array}$ \\
\hline Nucleated cells (cells/mcl) & $3.8 \pm 4.2$ & $2.8 \pm 3.2$ & $67.2 \pm 95.4$ & $287.7 \pm 433.2$ & $\begin{array}{l}\text { Control vs HGIVH (0.0079) and PHH } \\
(0.0005) ; \mathrm{LGIVH} \text { vs HGIVH (0.011) and PHH } \\
(0.0010)\end{array}$ \\
\hline Lymphocytes (\%) & $25.7 \pm 16.3$ & $23.0 \pm 17.9$ & $10.4 \pm 4.5$ & $17.1 \pm 11.6$ & $\begin{array}{l}0.051 \\
\text { Control vs HGIVH (0.043) }\end{array}$ \\
\hline Neutrophils (\%) & $25.0 \pm 11.7$ & $30.0 \pm 30.3$ & $38.2 \pm 32.4$ & $49.4 \pm 28.7$ & 0.24 \\
\hline Monocytes (\%) & $48.7 \pm 22.9$ & $46.6 \pm 34.2$ & $39.6 \pm 32.6$ & $16.3 \pm 10.7$ & $\begin{array}{l}0.024 \\
\text { Control vs PHH (0.016) }\end{array}$ \\
\hline Macrophages (\%) & $10.2 \pm 9.2$ & $29.0 \pm 25.2$ & $28.3 \pm 38.2$ & $10.2 \pm 6.1$ & 0.23 \\
\hline \multicolumn{6}{|l|}{ Serum } \\
\hline WBC (K/cumm) & $12.1 \pm 6.6$ & $14.8 \pm 9.9$ & $15.0 \pm 10.0$ & $22.9 \pm 10.0$ & 0.051 \\
\hline \multicolumn{6}{|l|}{ Control vs PHH (0.042) } \\
\hline RBC (K/cumm) & $3.5 \pm 0.7$ & $3.7 \pm 0.9$ & $3.2 \pm 0.6$ & $3.5 \pm 0.4$ & 0.34 \\
\hline Platelet (K/cumm) & $329.6 \pm 134.9$ & $223.0 \pm 66.6$ & $202.9 \pm 104.5$ & $251.5 \pm 92.2$ & $\begin{array}{l}0.032 \\
\text { Control vs HGIVH }(0.030)\end{array}$ \\
\hline Neutrophils (\%) & $47.5 \pm 21.7$ & $46.1 \pm 25.1$ & $42.2 \pm 21.9$ & $55.0 \pm 13.4$ & 0.53 \\
\hline Lymphocytes (\%) & $40.7 \pm 20.0$ & $31.9 \pm 18.6$ & $36.5 \pm 17.7$ & $27.9 \pm 11.8$ & 0.37 \\
\hline Monocytes (\%) & $8.3 \pm 4.2$ & $11.3 \pm 4.5$ & $9.5 \pm 5.9$ & $12.0 \pm 5.4$ & 0.18 \\
\hline
\end{tabular}

Values are reported as N (column \%) or mean \pm standard deviation. In the "P value' column, ANOVA summary p-value was recorded on the top row while significant pairwise post-test $P$ value were recorded on the bottom row. All pairwise comparisons were analyzed based on Dunn's or Tukey's post-test ANOVA depending on the distribution of the data (normal distribution or not). Cell differential reported as \% of total WBC. WBC, white blood cells; RBC, red blood cells

(median $47.0 \mathrm{mg} / \mathrm{dL}$ with IQR of 12), and HGIVH (median $42.5 \mathrm{mg} / \mathrm{dL}$ with IQR of 15.7). This represents a $27.5 \mathrm{mg} / \mathrm{dL}$ or $1.6 \mathrm{mmol} / \mathrm{L}$ decrease in the mean glucose concentration in $\mathrm{PHH}$ compared to control. There was no change in serum calculated osmolality, total protein, or glucose across all groups.

\section{CSF sodium, potassium, chloride}

CSF sodium $\left(\mathrm{Na}^{+}\right)$concentration was increased in $\mathrm{PHH}$ (median $170 \mathrm{mmol} / \mathrm{L}$ with IQR of 58) compared to all other groups (median (IQR): control 141.0 [12]; LGIVH 146.0 [10]; HGIVH 148.0 [28] mmol/L) (Fig. 2) consistent with a $38 \mathrm{mmol} / \mathrm{L}$ absolute increase in mean $\mathrm{Na}^{+}$ concentration in $\mathrm{PHH}$ compared to control. Similarly, CSF potassium $\left(\mathrm{K}^{+}\right)$concentration was elevated in $\mathrm{PHH}$ (median $4.4 \mathrm{mmol} / \mathrm{L}$ with IQR of 1.0) compared to control (median $3.1 \mathrm{mmol} / \mathrm{L}$ with IQR of 0.6 ), LGIVH (median $3.1 \mathrm{mmol} / \mathrm{L}$ with IQR of 0.7 ), and HGIVH (median $3.2 \mathrm{mmol} / \mathrm{L}$ with IQR of 0.4 ). Median and IQR for CSF chloride $\left(\mathrm{Cl}^{-}\right)$concentration in Control, LGIVH, HGIVH, and PHH were 119.0 (16.0); 121 (5.8); 123.0 (23.0); and 138.0 [43] mmol/L respectively. Mean CSF $\mathrm{Cl}^{-}$concentration was elevated in $\mathrm{PHH}$ compared to control by $21 \mathrm{mmol} / \mathrm{L}$. Notably, serum values for $\mathrm{Na}+$, $\mathrm{K}+$, and $\mathrm{Cl}$ - were similar across all groups.

\section{CSF magnesium, calcium, bicarbonate}

CSF magnesium $\left(\mathrm{Mg}^{2+}\right)$ concentration was elevated in $\mathrm{PHH}(3.7 \pm 0.8 \mathrm{mg} / \mathrm{dL})$ compared to control $(2.6 \pm 0.6 \mathrm{mg} / \mathrm{dL} ; \mathrm{p}=0.031)$ and LGIVH $(2.5 \pm 0.3 \mathrm{mg} /$ $\mathrm{dL} ; \mathrm{p}=0.041)$ but not HGIVH $(3.1 \pm 0.6 \mathrm{mg} / \mathrm{dL} ; \mathrm{p}=0.46)$ (Table 3). Concentration of calcium $\left(\mathrm{Ca}^{2+}\right)$ was significantly higher in $\mathrm{PHH}(4.3 \pm 0.3 \mathrm{mg} / \mathrm{dL})$ compared to control $(2.9 \pm 0.7 \mathrm{mg} / \mathrm{dL} ; \mathrm{p}=0.012), \mathrm{LGIVH}(1.7 \pm 0.8 \mathrm{mg} /$ $\mathrm{dL}, \quad \mathrm{p}<0.0001)$, but not $\mathrm{HGIVH}(3.3 \pm 0.9 \mathrm{mg} / \mathrm{dL}$, $\mathrm{p}=0.21$ ). This is a $1.0 \mathrm{mg} / \mathrm{dL}$ or $0.07 \mathrm{mmol} / \mathrm{L}$ absolute increase in mean $\mathrm{Mg}^{2+}$ concentration and $1.5 \mathrm{mmol} / \mathrm{L}$ increase in $\mathrm{Ca}^{2+}$ in $\mathrm{PHH}$ compared to control. Carbon dioxide $\left(\mathrm{CO}_{2}\right)$ concentration, a reflection of bicarbonate ion concentration and $\mathrm{pH}$, showed variable differences among groups with differences observed between $\mathrm{PHH}$ $(19.8 \pm 1.0 \mathrm{mmol} / \mathrm{L})$ and HGIVH $(19.5 \pm 2.3 \mathrm{mmol} / \mathrm{L})$ compared to LGIVH $(13.3 \pm 2.3 \mathrm{mmol} / \mathrm{L} ; \mathrm{p}=0.019$ and 0.010 respectively) but not control $(17.3 \pm 4.3 \mathrm{mmol} / \mathrm{L})$. Similarly, there is no change in serum calcium or bicarbonate across all groups.

\section{Degree of electrolytes change in CSF in PHH compared to control}

The largest measured contributor to the osmolality change in PHH CSF appeared to be sodium (absolute change of $37.6 \mathrm{mmol} / \mathrm{L}$ ), followed by chloride 


\section{CSF}

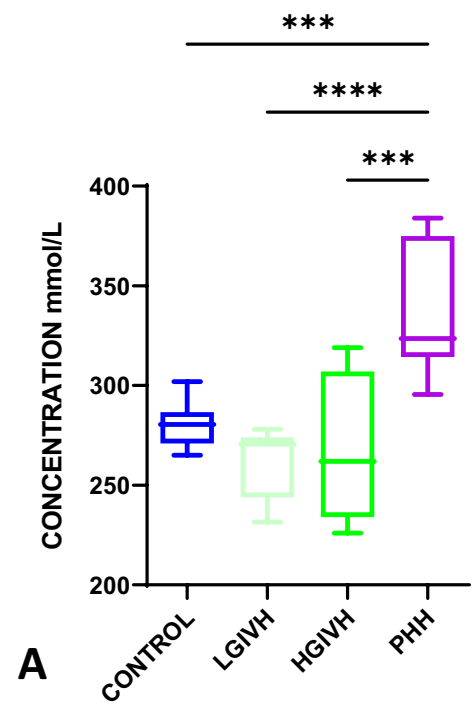

\section{Serum} Calculated Osmolality

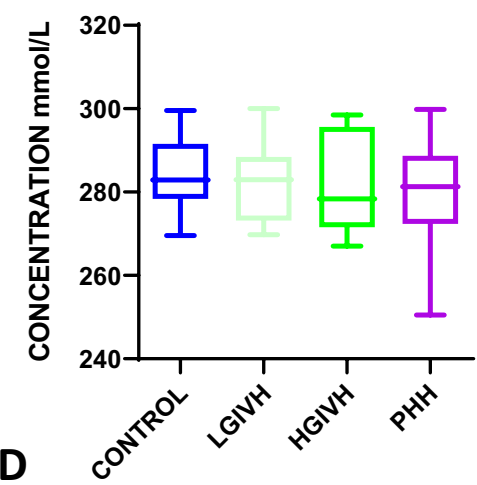

Total Protein
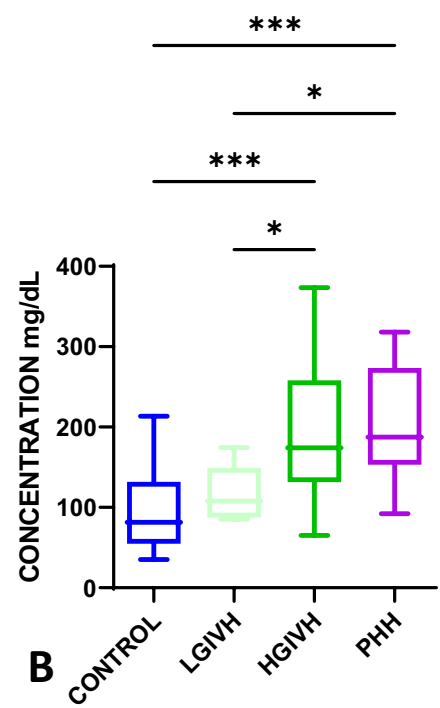

Total protein

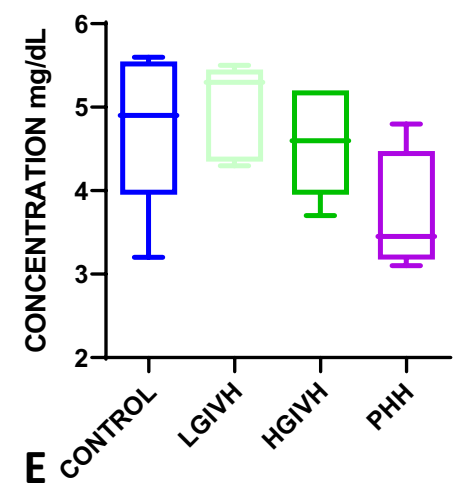

\section{Glucose}

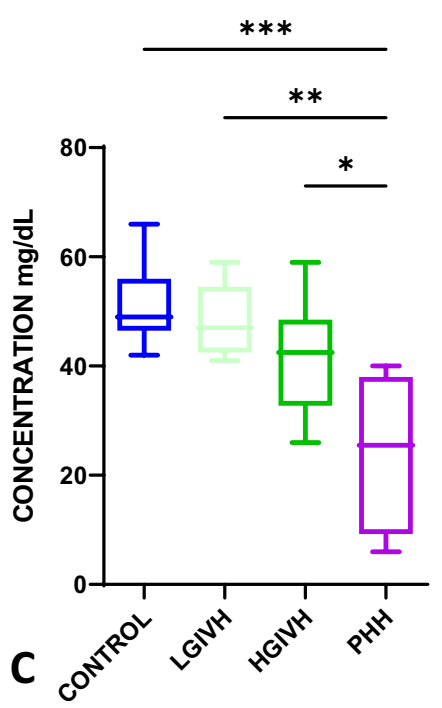

Fig. 1 CSF and serum osmolality, total protein, and glucose in human infants with PHH. A chart showing increased CSF osmolality in PHH ( $n=7$ ) compared to control $(n=12)$, low grade IVH $(n=7)$, and high grade IVH $(n=7)(p=0.0006,<0.0001,0.0003$ respectively; Tukey's post-test ANOVA). B chart showing increased total protein concentration in HGIVH $(n=11)$ and PHH $(n=11)$ compared to control $(n=16)(p=0.0009$ and 0.0006 respectively Tukey's post-test ANOVA) and LGIVH $(n=9)(p=0.034$ and 0.028 respectively Tukey's post-test ANOVA). C chart showing decreased glucose in PHH $(n=5)$ compared to control $(n=12), \operatorname{LGIVH}(n=7)$, and HGIVH $(n=7)(p=0.0002,0.0047$, and 0.041 respectively Tukey's post-test ANOVA). D chart showing no change in serum calculated osmolality across all the groups (ANOVA summary $p$-value $=0.71)(n=19 \mathrm{control}, 9 \mathrm{LGIVH}$, $7 \mathrm{HGIVH}$, and $11 \mathrm{PHH}$ ). $\mathbf{E}$ chart showing no change in serum total protein across all the groups (ANOVA summary $p$-value $=0.11)(n=5 \mathrm{control}, 5$ $\mathrm{LGIVH}, 5 \mathrm{HGIVH}$, and $4 \mathrm{PHH})$. $\mathbf{F}$ chart showing no change in serum glucose across all the groups (ANOVA summary $p$-value $=0.37)(\mathrm{n}=12 \mathrm{control}, 7$ LGIVH, 7 HGIVH, 5 PHH)

$(20.9 \mathrm{mmol} / \mathrm{L})$ (Table 4). Total protein contributed $5.9 \mathrm{mmol} / \mathrm{L}$ to the increase in osmolality in PHH CSF. However, it showed the largest change in concentration in the CSF, with an increase of $111.3 \%$ followed by glucose with a decrease of $55.2 \%$.
Association between electrolytes, and osmolality and CSF cell counts

To further evaluate the possible causes of osmolality and electrolyte changes and its relationship to ventricular volume, we calculated the correlations shown 


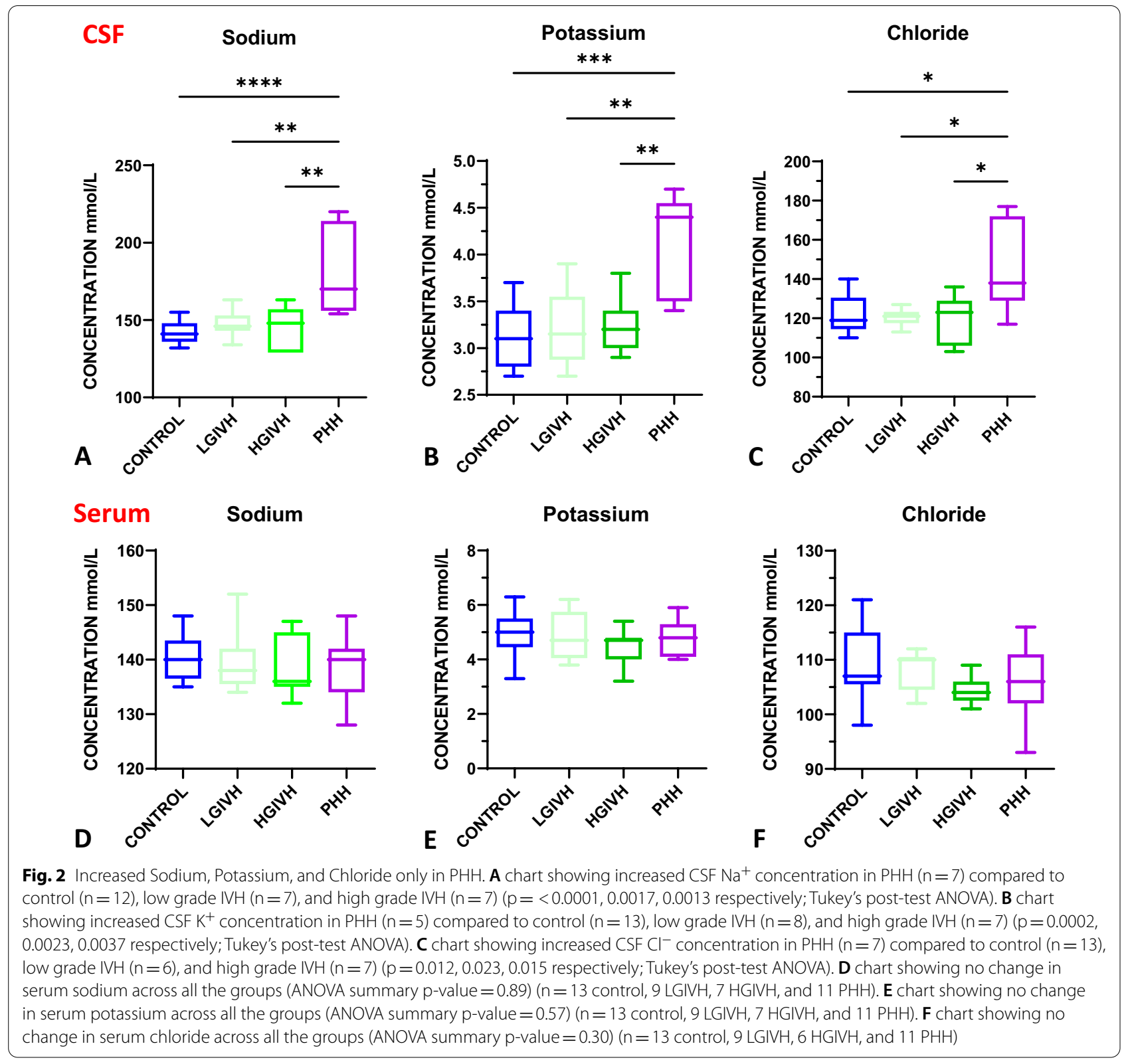

in Additional file 1: Table S2. Osmolality positively correlated with $\mathrm{Na}(\mathrm{r}, \mathrm{p}=0.55,0.0015), \mathrm{K}(\mathrm{r}, \mathrm{p}=0.51,0.0041)$, $\mathrm{Cl} \quad(\mathrm{r}, \mathrm{p}=0.60,0.0004), \quad \mathrm{Ca} \quad(\mathrm{r}, \mathrm{p}=0.49,0.0075), \quad \mathrm{Mg}$ $(\mathrm{r}, \mathrm{p}=0.58,0.0026)$ but not total protein $(\mathrm{r}, \mathrm{p}=0.11,0.59)$. Total nucleated cells positively correlated with osmolality, $\mathrm{Na}, \mathrm{K}, \mathrm{Mg}$, and total protein $(\mathrm{r}, \mathrm{p}=0.48,0.025 ; 0.54,0.014$; $0.49,0.024 ; 0.61,0.0036 ; 0.61,0.0008)$ but negatively correlated with glucose $(\mathrm{r}, \mathrm{p}=-0.65,0.0018)$. FOR was not correlated significantly with osmolality, $\mathrm{Na}, \mathrm{K}, \mathrm{Cl}$ or total protein $(\mathrm{r}, \mathrm{p}=0.48,0.11 ; 0.41,0.21 ; 0.48,0.12 ; 0.25,0.45$; and $0.59,0.12$ ). There were no significant correlations between individual electrolyte concentration, total protein, and osmolality with any individual WBC lineage (lymphocyte, neutrophil, monocyte, macrophage).

\section{Discussion}

Osmolality and thus electrolyte concentration have been implicated in the development of ventriculomegaly [38, $54,55]$. However, no study has quantified CSF osmolality and electrolyte concentrations in humans with IVH/ PHH. Our results show elevated CSF osmolality, total protein, $\mathrm{Na}, \mathrm{K}, \mathrm{Cl}, \mathrm{Mg}$, Ca in $\mathrm{PHH}$ compared to control. To further assess the relationship of the serum to the CSF, we evaluated these same electrolytes in the serum 
Table 3 Increased CSF Calcium and Magnesium in PHH but no difference in Bicarbonate compared to Control

\begin{tabular}{|c|c|c|c|c|c|c|}
\hline & & Control & LGIVH & HGIVH & $\mathrm{PHH}$ & $P$ value \\
\hline Magnesium & CSF & $2.6 \pm 0.6(n=13)$ & $2.5 \pm 0.3(n=6)$ & $3.1 \pm 0.6(n=6)$ & $3.7 \pm 0.8(n=4)$ & $\begin{array}{l}0.024 \\
\text { Control vs PHH (0.031); and LGIVH vs PHH (0.041) }\end{array}$ \\
\hline \multirow[t]{2}{*}{ Calcium } & CSF & $2.9 \pm 0.7(n=15)$ & $1.7 \pm 0.8(n=7)$ & $3.3 \pm 0.9(n=7)$ & $4.3 \pm 0.3(n=4)$ & $\begin{array}{l}<0.0001 \\
\text { Control vs LGIVH (0.013) and PHH (0.012); LGIVH } \\
\text { vs HGIVH }(0.0046) \text { and PHH }(<0.0001)\end{array}$ \\
\hline & Serum & $9.9 \pm 0.5(n=9)$ & $9.5 \pm 0.6(n=5)$ & $9.8 \pm 0.4(n=6)$ & $10.1 \pm 0.3(n=5)$ & 0.21 \\
\hline \multirow[t]{2}{*}{ Bicarbonate } & CSF & $17.3 \pm 4.3(n=13)$ & $13.3 \pm 2.3(n=7)$ & $19.5 \pm 2.3(n=6)$ & $19.8 \pm 1.0(n=4)$ & $\begin{array}{l}0.0062 \\
\text { LGIVH vs HGIVH (0.010) and PHH (0.019) }\end{array}$ \\
\hline & Serum & $24.9 \pm 4.4(n=13)$ & $25.1 \pm 1.6(n=8)$ & $24.3 \pm 2.8(n=6)$ & $25.9 \pm 4.4(n=11)$ & 0.85 \\
\hline
\end{tabular}

Values recorded as mean \pm standard deviation. In the " $P$ value' column, ANOVA summary $p$-value was recorded on the top row while significant pairwise post-test $P$ value were recorded on the bottom row. All pairwise comparisons were analyzed based on Dunn's or Tukey's post-test ANOVA depending on the distribution of the data (normal distribution or not). n, represents sample size

Table 4 Absolute and Percent change in electrolyte concentrations in PHH compared to Control

\begin{tabular}{|c|c|c|c|c|}
\hline & Control (mmol/L) & $\mathrm{PHH}(\mathrm{mmol} / \mathrm{L})$ & Absolute change (mmol/L) & $\begin{array}{l}\text { Percent } \\
\text { change } \\
(\%)\end{array}$ \\
\hline Total protein & 5.3 & 11.2 & 5.9 & 111.3 \\
\hline Glucose & 2.9 & 1.3 & -1.6 & -55.2 \\
\hline Sodium & 142.3 & 179.9 & 37.6 & 26.4 \\
\hline Potassium & 3.1 & 4.1 & 1 & 32.3 \\
\hline Chloride & 122.4 & 143.3 & 20.9 & 17.1 \\
\hline Bicarbonate & 17.3 & 19.8 & 2.5 & 14.5 \\
\hline Calcium & 0.16 & 0.24 & 0.08 & 50.0 \\
\hline Magnesium & 0.14 & 0.21 & 0.07 & 50.0 \\
\hline Calculated Total Osmoles & 296.2 & 364.1 & 67.9 & \\
\hline Measured Osmolality & 280.8 & 336.5 & 55.7 & 19.8 \\
\hline Unaccounted Osmoles & 15.4 & 27.6 & 12.2 & \\
\hline
\end{tabular}

Absolute change is the difference in concentration between the Control and PHH values. Percent change is the difference divided by the control value and multiplied by 100 . Calculated total osmoles is the sum of the electrolytes, total protein, and glucose in each group (control or PHH). Measured osmolality is the mean osmolality obtained from actual measurement with VAPRO osmometer. Unaccounted osmoles represent the difference in the calculated total osmoles and the measured osmolality

and observed no difference between the groups. With much evidence demonstrating $\mathrm{PHH}$ as a neuroinflammatory condition, we compared the WBC counts and differential in both CSF and serum. Our results showed total cells, total nucleated cells, and monocytes were higher in the CSF while only total WBC count was elevated in the serum with no changes in the cell differential in $\mathrm{PHH}$ compared to control. Finally, using correlation analyses, we evaluated the relationship of these parameters to ventricular size (using FOR) and cellularity (particularly total white blood cell and differential). We observed positive correlations between total nucleated cells and osmolality, sodium, and potassium. However, we observed no correlations between FOR and electrolytes concentration or osmolality.

Mean control CSF osmolality $(280.8 \mathrm{mmol} / \mathrm{L}), \mathrm{Na}$ $(142.3 \mathrm{mmol} / \mathrm{L}), \mathrm{K}(3.1 \mathrm{mmol} / \mathrm{L}), \mathrm{Cl}(122.4 \mathrm{mmol} / \mathrm{L})$,
$\mathrm{CO} 2(17.3 \mathrm{mmol} / \mathrm{L})$, were within the range of previously published studies [56]. Serum electrolyte concentration and osmolality were also within normal clinical reference range (Additional file 1: Table S1). The CSF osmolar gap (measured CSF osmolality difference from calculated CSF osmolality) (Table 4) could be due to unmeasured anions such as inorganic phosphates, and/or total free water content.

Osmolality is one of the driving forces for water movement across a cell layer $[57,58]$. The contributors to osmolality are mostly ions but proteins also contribute to this osmotic pressure. Oncotic pressure is another driver of water transport and is created solely by protein concentration. The increase in CSF osmolality in $\mathrm{PHH}$ indicates an increase in the driving force of water into the ventricles and could be a major contributor to ventriculomegaly $[38,54,55,59]$. Our results show that 
CSF osmolality in all IVH grades was similar to control but was elevated in PHH. It is interesting that clinically, IVH progresses to $\mathrm{PHH}$ when there is documented progressive ventricular dilatation and clinical signs of increased intracranial pressure (ICP). Normal electrolyte concentrations and osmolality in HGIVH compared to control even in the presence of ventricular enlargement $($ FOR $>0.5)$ [60] could indicate sufficient compensation by water transport into the CSF space. This compensation could maintain normal osmolality but be associated with larger ventricles, as observed in HGIVH. It is thus possible that, $\mathrm{PHH}$ is associated with uncompensated physiology with permissive increases in electrolyte and protein concentrations and osmolality, with progressive fluid imbalance, ventricular enlargement, and intracranial pressure [61] requiring CSF diversion.

The elevation in PHH CSF osmolality is interesting, as one would expect fluid movement to achieve equilibrium at or near normal CSF osmolality. Indeed, we found that PHH CSF osmolality was uniformly elevated relative to serum. This is likely due to limitation of water transport and thus ventricular dilatation by the ventricular wall compliance, hydrostatic pressure, and ICP [61]. In addition, the pathologic state (e.g. ChP hypersecretion, inflammation) in PHH may be sustained [15]; therefore, continuous electrolyte secretion without equivalent water transport into the ventricles leading to a dynamic equilibrium state. In this state, CSF osmolality might remain elevated even though the epithelium continues to transport water both transcellularly and paracellularly (if brain-CSF-barrier (BCSFB) is disrupted) [56] in an attempt to restore normal CSF osmolality. Another consideration is increased CSF osmolality should reasonably lead to cell shrinkage and activation of antidiuretic hormone (ADH); and some clinical observations show possible changes in $\mathrm{ADH}$ in hydrocephalus [62-66]. However, in a state of dynamic equilibrium and restriction to water transport into the ventricles by the factors mentioned earlier, it is possible for serum and epithelial cell osmolality to be normal while CSF osmolality remains elevated. Also, it is conceivable that if the BCSFB is disrupted in PHH as suggested by other studies $[67,68]$, water transport across the ChP will now become primarily paracellular (lower resistance flow) and this will reasonably exclude the cell as an intermediate compartment and cell osmolality and size might remain normal. At this point, the pathophysiology remains unclear, but our results suggest that there is aberrant transport of water across the different fluid compartments in $\mathrm{PHH}$. As such, future studies to further evaluate total water content in the CSF and direction of water flow in PHH as well as ChP epithelial cell size and osmolality should be conducted. Recent studies have suggested that this water transport is likely disrupted in $\mathrm{PHH}[17,69-71]$. Other components of transport across the ChP epithelial (lateral intercellular space and/or claudin integrity and activity) should be investigated as well.

Water transport into the ventricular space could be originating from the ChP capillaries via AQP1 channels (if the BCSFB is intact) on the ChP apical membrane $[72,73]$ or from the brain parenchyma, sometimes mediated by AQP4 [74]. Unfortunately, AQP1 mediated water transport in $\mathrm{PHH}$ remains controversial. Some studies have shown decreased, unchanged, and increased activity of AQP1 in different forms of hydrocephalus [16, 17, 59, 75]. In the case of BCSFB disruption, which may occur in $\mathrm{PHH}$, water transport across the $\mathrm{ChP}$ is no longer restricted to transcellular transport and may freely move down the osmotic gradient while being regulated by other forces such as hydrostatic pressure, ventricular wall compliance, and ICP as mentioned earlier. On the other hand, AQP4 is closely related to glymphatics, another putative system involved in CSF homeostasis. This system argues the existence of a fluid connection between the CSF space, brain parenchyma, and the perivascular spaces. Hydrostatic pressure generated by the arteries and AQP4 mediated water transport are two mechanisms by which the system moves fluid from the CSF space to the venous structures and peri-neural spaces $[8,71]$. Impairment of the glymphatic clearance of CSF has been shown in IVH and $\mathrm{PHH}$ [71]. Serum and CSF osmolality do not vary much in normal state hence the osmotic pressure might not contribute much to this fluid movement in a "normal" infant. However, in a pathologic state such as $\mathrm{PHH}$ with such elevated CSF osmolality and reduced oncotic gradient (Additional file 1: Table S1), osmotic and oncotic pressures possibly become important drivers. The increased CSF osmotic and oncotic pressure in $\mathrm{PHH}$ may be one of the mechanisms, in conjunction with changes in AQP4 expression and distribution, which leads to the disruption of the glymphatic system described in IVH/ $\mathrm{PHH}$.

Similar to previous studies [34, 36, 37, 76], our results show that osmolality changes in the CSF are mostly driven by changes in electrolytes especially sodium and chloride concentration. As expected, sodium and chloride concentrations are elevated in $\mathrm{PHH}$ compared to control and all IVH grades. The change in sodium concentration contributes over $50 \%$ of the change in osmolality (Table 4). However, protein concentration is believed to contribute only minimally to osmolality $[29,37]$ and similarly, our results show that change in protein concentration only contributes about $8 \%$ to osmolality change (Table 4). In addition, compared to control, total protein concentrations are increased in both HGIVH and PHH but osmolality, sodium, and chloride concentrations are 
increased in $\mathrm{PHH}$ only. Osmolality also positively correlated with $\mathrm{Na}, \mathrm{K}, \mathrm{Cl}, \mathrm{Mg}$, and $\mathrm{Ca}$ but not total protein (Table 4). These all further support the notion that proteins, compared to electrolyte, likely contribute less to CSF osmolality changes.

$\mathrm{PHH}$, though described clinically by signs and symptoms of ventriculomegaly and elevated ICP, is likely preceded by complex cytopathologies such as ChP CSF hypersecretion $[15,59,77]$, inflammation $[8,77-79]$, and cell-junction disruption in the ventricular zone [11]. These pathologies are not restricted to $\mathrm{PHH}$ alone but also occur in IVH. Though the mechanism for development of PHH after IVH is unclear, these electrolyte changes are likely occurring after these cytopathologies as there are no observed changes in any IVH grade. Therefore, it is also unclear if these electrolyte changes are a cause or result of ventriculomegaly. It may appear they are at least likely contributors to ventricular dilatation $[38,54,55]$ and development of $\mathrm{PHH}$ from IVH as explained earlier. Though the ependyma plays a significant role in water transport and CSF homeostasis; ion transport across it is not well described probably due to its highly permeable extracellular spaces [80] and the ChP being the major secretory organ in the central nervous system. The ChP is also one of the highest secretory epithelia in the body, contributing up to $80 \%$ of CSF production, and the major regulator of CSF content $[72,81][72$, $73,82-84]$. Thus, while the ChP epithelium is an important primary contributor to the electrolyte and osmolality changes we observed in this study, other possible contributors include BCSFB disruption and inflammatory processes. ChP hypersecretion occurs via increased expression of the NKCC1 $[15,59,81]$, a bidirectional transporter of $\mathrm{Na}, \mathrm{K}$, and $\mathrm{Cl}$ involved in the net secretion of $\mathrm{Cl}$ into the ventricles for CSF production in normal state $[56,84]$. NKCC1 channel hyperactivity might be responsible for increased CSF $\mathrm{Na}, \mathrm{K}$, and $\mathrm{Cl}$ ions in $\mathrm{PHH}$; however, as described earlier, these changes would have to be in the context of abnormal water transport.

$\mathrm{CO} 2$, as a surrogate for bicarbonate which is the major driver of CSF $\mathrm{pH}$ [85], was not significantly increased compared to control; however, the CSF/serum ratio in $\mathrm{PHH}$ increased compared to control (Additional file 1: Table S1). It may be that our sample size was underpowered to detect differences between control and PHH. Any increased in $\mathrm{CO} 2$ might reflect activation of the $\mathrm{Na}$ dependent $\mathrm{Cl}$ transporter $(\mathrm{NBCe} 2)$, which has been implicated in hydrocephalus $[56,59,86]$. It is important to note that $\mathrm{CO} 2$ passively diffuses across the BCSFB but normal serum $\mathrm{CO} 2$ and high $\mathrm{CSF} \mathrm{CO}_{2}$ in $\mathrm{PHH}$ might suggest $\mathrm{H}^{+}$and $\mathrm{HCO}^{-}$ion transport, implicating $\mathrm{BCSFB}$ disruption rather than $\mathrm{CO} 2$ diffusion. The sodium-hydrogen exchanger (NHE1), a channel that delivers sodium into the CSF while moving hydrogen ion out, might also be involved in CSF bicarbonate changes. If hyperactive in $\mathrm{PHH}$, this could be contributing to the increased $\mathrm{Na}$ and $\mathrm{pH}$ in the CSF of infants with $\mathrm{PHH}$. Further studies to examine the activity of both channels in PHH should be conducted.

$\mathrm{Mg}$ is also significantly increased in $\mathrm{PHH}$ compared to control, but it is unclear at this point what might be leading to this change. One possibility is the inflammatory response as $\mathrm{Mg}$ is positively correlated with nucleated cells. Total nucleated cells were also positively correlated with $\mathrm{Na}, \mathrm{K}$, osmolality, and total proteins indicating that inflammation might also be involved in the elevation of other CSF electrolytes and total protein. Many animals, in vitro, and human studies have shown increased cytokines and chemokines in $\mathrm{PHH}$ which might contribute to the total protein concentration $[2,18]$. However, the increased total protein may be related to blood and its metabolites. Other studies $[6,29]$ have also shown increased total protein in $\mathrm{PHH}$ as well as increased hemoglobin, other blood metabolites, and hemoglobin associated proteins in $\mathrm{PHH}$. Further emphasizing the possible involvement of inflammation in CSF biochemical profile changes is decreased glucose in $\mathrm{PHH}$ compared to control, LGIVH, and HGIVH. Decreased CSF glucose is clinically associated with neuro-inflammation as it is a common finding across many neuro-inflammatory conditions including meningitis. Altogether, these solutes (total protein, $\mathrm{Mg}, \mathrm{Ca}$, glucose) likely have minor contribution to osmolality changes.

The disruption of the BCSFB is another pathology that might contribute to the electrolyte, total protein, and osmolality changes $[33,59,87,88]$. Of note, CSF osmolality and the concentrations of many electrolytes exceed serum levels in $\mathrm{PHH}$. This suggests that the electrolyte changes were not simply the result of serum and CSF mixing. In addition, the serum concentration of all electrolytes did not change in PHH compared to control. On the other hand, impairment in macromolecule efflux channels present on the BCSFB have been described in hydrocephalus [55, 89]. These changes were associated with CSF osmolality and might also contribute to the complex etiology of CSF hyperosmolality in PHH. Our data indicate that CSF electrolyte and osmolality changes are due to more complex processes, including ChP hypersecretion or inflammation.

Finally, maintaining a normal CSF biochemical profile is essential for normal neurodevelopment and neuronal activity especially at the neonatal age period [90]. CSF contents have been shown to affect neural progenitor cell behavior (proliferation and differentiation), brain patterning, and neurogenesis [87, 91, 92] and may be related to some of the neurodevelopmental 
impairments observed in children with $\mathrm{PHH}$. This further emphasizes the importance of this study and future studies should evaluate the interaction of CSF electrolytes, the neurogenic niche, and neurodevelopmental outcomes.

\section{Limitations}

A few limitations in this study must be acknowledged. $\mathrm{IVH} / \mathrm{PHH}$ is more prevalent in males with about $60 \%$ of cases affecting males [93-95] but, of note, our cohort includes a higher percentage of males (about 77\%) and thus could introduce bias in the results. However, in our subgroup analyses to examine the effect of sex on biochemical profile, we did not observe differences (Additional file 1: Tables S3-S4). Sample variation (including high standard deviations in some analyses) due to limited sample size and inevitable variation in sample acquisition, processing, storage, as well as natural clinical heterogeneity within and between groups. Though we are unable to determine the precise time germinal matrix hemorrhage occurred, about $50 \%$ of IVH cases occur within $6-8 \mathrm{~h}$ after birth and $90 \%$ by 3 days after birth [96, 97]. The time from birth to LP for control, LGIVH, HGIVH, PHH are $7.1 \pm 4.8,1.5 \pm 1.8,4.7 \pm 3.8$, and $2.5 \pm 1.3$ weeks respectively. The LGIVH group had earlier LP sampling compared to the control only $(p=0.001)$. LPs were obtained for clinical purposes per the primary care team accounting for the variability in timing of sample acquisition. Lumbar CSF samples were used in this study, but ventricular CSF samples will be evaluated in future studies to address possible rostral-caudal gradient differences. This study utilized a small sample size especially in some of the electrolyte analysis and future studies with larger sample size need to be conducted to further validate the results of this study.

\section{Conclusions}

In this study, we report the novel finding of increased CSF concentration of $\mathrm{Na}, \mathrm{K}, \mathrm{Cl}, \mathrm{Ca}, \mathrm{Mg}$, and osmolality in infants with PHH. Changes in CSF osmolality are most likely driven by changes in sodium and electrolyte concentrations rather than protein concentrations. These changes in the CSF were independent of the serum as we found no changes in serum electrolytes across the groups. However, we observed positive correlations between CSF total nucleated cells and CSF osmolality, $\mathrm{Na}$, and $\mathrm{K}$. Total cells and nucleated cells in the CSF were increased in PHH. Serum WBC count was also increased in PHH but no differences in the WBC differential. These findings provide important insights into the pathophysiology of IVH and PHH.

\section{Supplementary Information}

The online version contains supplementary material available at https://doi. org/10.1186/s12987-021-00295-8.

Additional file 1: Table S1. CSF and serum electrolyte concentrations in control individuals as well as CSF/Serum electrolyte ratio in control and $\mathrm{PHH}$. Table S2. Correlations between electrolytes and osmolality, and CSF cell counts. Table S3. Subgroup analysis by sex of cerebrospinal fluid total protein, osmolality, and electrolytes in $\mathrm{PHH}$. Sample size limitations permitted analysis only of the male cohort; there were insufficient samples for analysis by female sex. To address this limitation, regression analysis examining sex as an explanatory variable was also performed (please refer to Table S4). Values recorded as mean \pm standard deviation. In the "P value' column, ANOVA summary p-value was recorded on the top row while significant pairwise post-test $P$ value were recorded on the bottom row. All pairwise comparisons were analyzed based on Dunn's or Tukey's post-test ANOVA depending on the distribution of the data (normal distribution or not). $n$, represents sample size. Table S4. F, t, and $p$ values from regression analyses evaluating sex as an explanatory variable. Analysis of all CSF parameters resulted in non-significant $p$-values indicating sex is not an explanatory variable for differences in the CSF parameters. $\mathrm{F}=\mathrm{F}$-value; $\mathrm{t}=\mathrm{t}$-value; and $\mathrm{p}=\mathrm{p}$-value. Figure $\mathbf{S 1}$. Ultrasonographic image representation of Control, IVH and $\mathrm{PHH}$

\section{Acknowledgements}

We acknowledge Dr. Gereau and his team for assistance with the osmometry. We also thank Dr. Jennifer Powers Carson and the Washington University Core Laboratory for Clinical Services for their work in measuring CSF electrolytes. Finally, we would like to thank the patients and families who generously participated in this study and the members of the Washington University/St. Louis Children's Hospital Neurosurgery and NICU teams who participated in their care.

\section{Authors' contributions}

$\mathrm{AO}$ and DDL conceived of the presented idea. AO, DM, LC, JPM, SG, and $\mathrm{DDL}$ developed the theory, study design, specimen acquisition, and fund management. AO performed the measurements and computations. YY and $D D L$ verified the analytical methods. MG, Al, and JS assisted AO with the development of the manuscript. SG contributed to overall interpretation of physiologic implications of study result and encouraged $\mathrm{AO}$ to discuss elevated CSF osmolality in the setting of normal serum osmolality as it relates to water transport, cell size, and ADH, DDL supervised the findings of this work. All authors discussed the results and contributed to the final manuscript.

\section{Funding}

This study was conducted using institutional funding.

Availability of data and materials

The datasets used and/or analyzed during the current study are available from the corresponding author on reasonable request.

\section{Declarations}

\section{Ethics approval and consent to participate}

This study was approved by the Human Research Protection Office/Institutional Review Board at Washington University in St. Louis approved with a waiver of written informed consent (HRPO\# 201203126).

\section{Consent for publication \\ Not applicable.}

\section{Competing interests}

D.D.L. and J.P.M. have received research funding and/or equipment for unrelated research through Medtronic, Inc., Microbot Medical, Inc., and Karl Storz, Inc.

Other authors have no competing interests. 


\begin{abstract}
Author details
${ }^{1}$ Department of Neurosurgery, Washington University in St. Louis School of Medicine, St. Louis, MO 63110, USA. ${ }^{2}$ Department of Nephrology, Washington University in St. Louis School of Medicine, St. Louis, MO 63110, USA. ${ }^{3}$ Department of Surgery, Washington University in St. Louis School of Medicine, St. Louis, MO 63110, USA. ${ }^{4}$ Division of Neurosurgery, Department of Clinical Neurosciences, University of Calgary, Calgary, AB T2N 2T9, Canada. ${ }^{5}$ Children's Hospital Orange County, Children's Research Institute, Orange, CA 92868, USA.
\end{abstract}

Received: 29 September 2021 Accepted: 6 December 2021 Published online: 24 December 2021

\section{References}

1. Papile L-A, Burstein J, Burstein R, Koffler H. Incidence and evolution of subependymal and intraventricular hemorrhage: a study of infants with birth weights less than 1,500 gm. J Pediatr. 1978;92(4):529-34.

2. Morales DM, Silver SA, Morgan CD, Mercer D, Inder TE, Holtzman DM, et al. Lumbar cerebrospinal fluid biomarkers of posthemorrhagic hydrocephalus of prematurity: amyloid precursor protein, soluble amyloid precursor protein alpha, and L1 cell adhesion molecule. Neurosurgery. 2017:80(1):82-90.

3. Adams-Chapman I, Hansen NI, Stoll BJ, Higgins R, Network NR. Neurodevelopmental outcome of extremely low birth weight infants with posthemorrhagic hydrocephalus requiring shunt insertion. Pediatrics. 2008:121(5):e1167-77.

4. Robinson S. Neonatal posthemorrhagic hydrocephalus from prematurity: pathophysiology and current treatment concepts: a review. J Neurosurg Pediatr. 2012;9(3):242-58.

5. Bolisetty S, Dhawan A, Abdel-Latif M, Bajuk B, Stack J, Oei J-L, et al. Intraventricular hemorrhage and neurodevelopmental outcomes in extreme preterm infants. Pediatrics. 2014;133(1):55-62.

6. Mahaney KB, Buddhala C, Paturu M, Morales D, Limbrick DD Jr, Strahle JM. Intraventricular hemorrhage clearance in human neonatal cerebrospinal fluid: associations with hydrocephalus. Stroke. 2020;51(6):1712-9.

7. Limbrick DD, Morales DM, Shannon CN, Wellons JC, Kulkarni AV, Alvey JS, et al. Cerebrospinal fluid NCAM-1 concentration is associated with neurodevelopmental outcome in post-hemorrhagic hydrocephalus of prematurity. PLOS ONE. 2021;16(3):e0247749.

8. Karimy JK, Reeves BC, Damisah E, Duy PQ, Antwi P, David W, et al. Inflammation in acquired hydrocephalus: pathogenic mechanisms and therapeutic targets. Nat Rev Neurol. 2020;16(5):285-96.

9. Flores JJ, Klebe D, Tang J, Zhang JH. A comprehensive review of therapeutic targets that induce microglia/macrophage-mediated hematoma resolution after germinal matrix hemorrhage. J Neurosci Res. 2020;98(1):121-8

10. Castaneyra-Ruiz L, Morales DM, McAllister JP, Brody SL, Isaacs AM, Strahle $J M$, et al. Blood exposure causes ventricular zone disruption and glial activation in vitro. J Neuropathol Exp Neurol. 2018;77(9):803-13.

11. McAllister JP, Guerra MM, Ruiz LC, Jimenez AJ, Dominguez-Pinos D, Sival $D$, et al. Ventricular zone disruption in human neonates with intraventricular hemorrhage. J Neuropathol Exp Neurol. 2017;76(5):358-75.

12. Park R, Moon UY, Park JY, Hughes LJ, Johnson RL, Cho S-H, et al. Yap is required for ependymal integrity and is suppressed in LPA-induced hydrocephalus. Nat Commun. 2016;7(1):1-14.

13. Lummis NC, Sánchez-Pavón P, Kennedy G, Frantz AJ, Kihara Y, Blaho $V A$, et al. LPA1/3 overactivation induces neonatal posthemorrhagic hydrocephalus through ependymal loss and ciliary dysfunction. Sci Adv. 2019;5(10):eaax2011.

14. Isaacs AM, Smyser CD, Lean RE, Alexopoulos D, Han RH, Neil JJ, et al. MR diffusion changes in the perimeter of the lateral ventricles demonstrate periventricular injury in post-hemorrhagic hydrocephalus of prematurity. Neurolmage Clin. 2019;24:102031.

15. Karimy JK, Zhang J, Kurland DB, Theriault BC, Duran D, Stokum JA, et al. Inflammation-dependent cerebrospinal fluid hypersecretion by the choroid plexus epithelium in posthemorrhagic hydrocephalus. Nat Med. 2017;23(8):997.
16. Limbrick DD Jr, Castaneyra-Ruiz L, Han RH, Berger D, McAllister JP, Morales DM. Cerebrospinal fluid biomarkers of pediatric hydrocephalus. Pediatr Neurosurg. 2017;52(6):426-35.

17. Castañeyra-Ruiz L, Hernández-Abad LG, Carmona-Calero EM, CastañeyraPerdomo A, González-Marrero I. AQP1 overexpression in the CSF of obstructive hydrocephalus and inversion of its polarity in the choroid plexus of a chiari malformation type II case. J Neuropathol Exp Neurol. 2019;78(7):641-7.

18. Habiyaremye G, Morales DM, Morgan CD, McAllister JP, CreveCoeur TS, $\mathrm{Han} \mathrm{RH}$, et al. Chemokine and cytokine levels in the lumbar cerebrospinal fluid of preterm infants with post-hemorrhagic hydrocephalus. Fluids Barriers CNS. 2017;14(1):1-10.

19. Chow LC, Soliman A, Zandian M, Danielpour M, Krueger RC Jr. Accumulation of transforming growth factor- $\beta 2$ and nitrated chondroitin sulfate proteoglycans in cerebrospinal fluid correlates with poor neurologic outcome in preterm hydrocephalus. Neonatology. 2005:88(1):1-11.

20. Heep A, Stoffel-Wagner B, Bartmann P, Benseler S, Schaller C, Groneck $P$, et al. Vascular endothelial growth factor and transforming growth factor- $\beta 1$ are highly expressed in the cerebrospinal fluid of premature infants with posthemorrhagic hydrocephalus. Pediatr Res. 2004;56(5):768-74.

21. Kitazawa K, Tada T. Elevation of transforming growth factor-beta 1 level in cerebrospinal fluid of patients with communicating hydrocephalus after subarachnoid hemorrhage. Stroke. 1994;25(7):1400-4.

22. Whitelaw A, Christie S, Pople I. Transforming growth factor- $\beta 1$ : a possible signal molecule for posthemorrhagic hydrocephalus? Pediatr Res. 1999:46(5):576

23. Heep A, Bartmann P, Stoffel-Wagner B, Bos A, Hoving E, Brouwer O, et al. Cerebrospinal fluid obstruction and malabsorption in human neonatal hydrocephaly. Childs Nerv Syst. 2006;22(10):1249-55.

24. Lipina R, Reguli Š, Nováčková L, Podešvová H, Brichtová E. Relation between TGF- $\beta 1$ levels in cerebrospinal fluid and ETV outcome in premature newborns with posthemorrhagic hydrocephalus. Childs Nerv Syst. 2010;26(3):333-41.

25. Morales DM, Townsend RR, Malone JP, Ewersmann CA, Macy EM, Inder $T E$, et al. Alterations in protein regulators of neurodevelopment in the cerebrospinal fluid of infants with posthemorrhagic hydrocephalus of prematurity. Mol Cell Proteom. 2012;11(6):M111. 011973.

26. Morales DM, Holubkov R, Inder TE, Ahn HC, Mercer D, Rao R, et al. Cerebrospinal fluid levels of amyloid precursor protein are associated with ventricular size in post-hemorrhagic hydrocephalus of prematurity. PLoS ONE. 2015;10(3):e0115045.

27. Strahle JM, Garton T, Bazzi AA, Kilaru H, Garton HJ, Maher CO, et al. Role of hemoglobin and iron in hydrocephalus after neonatal intraventricular hemorrhage. Neurosurgery. 2014;75(6):696-706.

28. Savman K, Nilsson UA, Blennow M, Kjellmer I, Whitelaw A. Non-proteinbound iron is elevated in cerebrospinal fluid from preterm infants with posthemorrhagic ventricular dilatation. Pediatr Res. 2001;49(2):208-12.

29. Strahle JM, Mahaney KB, Morales DM, Buddhala C, Shannon CN, Wellons JC III, et al. Longitudinal CSF iron pathway proteins in post-hemorrhagic hydrocephalus: associations with ventricle size and neurodevelopmental outcomes. Ann Neurol. 2021;90(2):217-26.

30. Whitelaw A. Endogenous fibrinolysis in neonatal cerebrospinal fluid. Eur J Pediatr. 1993;152(11):928-30.

31. Whitelaw A, Creighton L, Gaffney P. Fibrinolysis in cerebrospinal fluid after intraventricular haemorrhage. Arch Dis Child. 1991;66(7 Spec No):808-9.

32. Cerda M, Manterola A, Ponce S, Basauri L. Electrolyte levels in the CSF of children with nontumoral hydrocephalus. Childs Nerv Syst. 1985;1(6):306-11.

33. Nagy G, Molnar L, Kovács T, Nyako G, Rochlitz S. Elektrolytgehalt des Liquor cerebrospinalis bei Hydrocephalus. Arch Psychiatr Nervenkr. 1979;226(4):319-24

34. Kiviranta T, Tuomisto L, Airaksinen EM. Osmolality and electrolytes in cerebrospinal fluid and serum of febrile children with and without seizures. Eur J Pediatr. 1996;155(2):120-5.

35. Wibroe EA, Yri HM, Jensen RH, Wibroe MA, Hamann S. Osmolality of cerebrospinal fluid from patients with idiopathic intracranial hypertension (IIH). PLOS ONE. 2016;11(1):e0146793.

36. Ohman JL Jr, Marliss EB, Aoki TT, Munichoodappa CS, Khanna VV, Kozak GP. The cerebrospinal fluid in diabetic ketoacidosis. N Engl J Med. 1971:284(6):283-90. 
37. Akaishi T, Takahashi T, Nakashima I, Abe M, Aoki M, Ishii T. Osmotic pressure of serum and cerebrospinal fluid in patients with suspected neurological conditions. Neural Regen Res. 2020;15(5):944.

38. Krishnamurthy S, Li J, Schultz L, Jenrow KA. Increased CSF osmolarity reversibly induces hydrocephalus in the normal rat brain. Fluids Barriers CNS. 2012;9(1):1-8.

39. Maraković J, Orešković D, Radoš M, Vukić M, Jurjević I, Chudy D, et al. Effect of osmolarity on CSF volume during ventriculo-aqueductal and ventriculo-cisternal perfusions in cats. Neurosci Lett. 2010;484(2):93-7.

40. Patra K, Wilson-Costello D, Taylor HG, Mercuri-Minich N, Hack M. Grades I-II intraventricular hemorrhage in extremely low birth weight infants: effects on neurodevelopment. J Pediatr. 2006;149(2):169-73.

41. Wellons JC, Shannon CN, Holubkov R, Riva-Cambrin J, Kulkarni AV, Limbrick DD, et al. Shunting outcomes in posthemorrhagic hydrocephalus: results of a Hydrocephalus Clinical Research Network prospective cohort study. J Neurosurg Pediatr. 2017;20(1):19-29.

42. Ezz-Eldin ZM, Hamid TAA, Youssef MRL, Nabil HE-D. Clinical risk index for babies (CRIB II) scoring system in prediction of mortality in premature babies. J Clin Diagn Res JCDR. 2015;9(6):08.

43. Feudtner C, Hays RM, Haynes G, Geyer JR, Neff JM, Koepsell TD. Deaths attributed to pediatric complex chronic conditions: national trends and implications for supportive care services. Pediatrics. 2001;107(6):e99-e.

44. Manktelow BN, Draper ES, Field DJ. Predicting neonatal mortality among very preterm infants: a comparison of three versions of the CRIB score. Arch Dis Child Fetal Neonatal Ed. 2010;95(1):F9-13.

45. Parry G, Tucker J, Tarnow-Mordi W, Group UNSSC. CRIB II: an update of the clinical risk index for babies score. Lancet. 2003;361(9371):1789-91.

46. Simon TD, Hall M, Riva-Cambrin J, Albert JE, Jeffries HE, LaFleur B, et al. Infection rates following initial cerebrospinal fluid shunt placement across pediatric hospitals in the United States. J Neurosurg Pediatr. 2009:4(2):156-65.

47. Han RH, McKinnon A, CreveCoeur TS, Baksh BS, Mathur AM, Smyser $C D$, et al. Predictors of mortality for preterm infants with intraventricular hemorrhage: a population-based study. Childs Nerv Syst. 2018;34(11):2203-13.

48. Simon TD, Butler J, Whitlock KB, Browd SR, Holubkov R, Kestle JR, et al. Risk factors for first cerebrospinal fluid shunt infection: findings from a multicenter prospective cohort study. J Pediatr. 2014;164(6):1462-8.e2.

49. Greenberg JK, Olsen MA, Yarbrough CK, Ladner TR, Shannon CN, Piccirillo JF, et al. Chiari malformation Type I surgery in pediatric patients. Part 2: complications and the influence of comorbid disease in California, Florida, and New York. J Neurosurg Pediatr. 2016;17(5):525-32.

50. Morales DM, Smyser CD, Han RH, Kenley JK, Shimony JS, Smyser TA, et al. Tract-specific relationships between cerebrospinal fluid biomarkers and periventricular white matter in posthemorrhagic hydrocephalus of prematurity. Neurosurgery. 2021;88(3):698-706.

51. Artru AA. Isoflurane does not increase the rate of CSF production in the dog. J Am Soc Anesthesiol. 1984;60(3):193-7.

52. Melton J, Nattie E. Brain and CSF water and ions during dilutional and isosmotic hyponatremia in the rat. Am J Physiol Regul Integr Comp Physiol. 1983;244(5):R724-32.

53. Artru AA. Reduction of cerebrospinal fluid pressure by hypocapnia: changes in cerebral blood volume, cerebrospinal fluid volume, and brain tissue water and electrolytes. J Cereb Blood Flow Metab. 1987;7(4):471-9.

54. Krishnamurthy S, Li J, Schultz L, McAllister JP. Intraventricular infusion of hyperosmolar dextran induces hydrocephalus: a novel animal model of hydrocephalus. Cerebrospinal Fluid Res. 2009;6(1):1-9.

55. Krishnamurthy S, Tichenor MD, Satish AG, Lehmann DB. A proposed role for efflux transporters in the pathogenesis of hydrocephalus. Croat Med J. 2014;55(4):366-76.

56. Praetorius J, Damkier HH. Transport across the choroid plexus epithelium. Am J Physiol Cell Physiol. 2017;312(6):C673-86

57. Koeppen B, Stanton B. Physiology of body fluids. Renal physiology, mosby physiology monograph series, 4th edn, vol. 206. Philadelphia, PA: Elsevier Inc.; 2013. P. 75-7.

58. Shah MM, Mandiga P. Physiology, plasma osmolality and oncotic pressure. StatPearls Publishing; 2019.

59. Hochstetler AE, Smith HM, Preston DC, Reed MM, Territo PR, Shim JW, et al. TRPV4 antagonists ameliorate ventriculomegaly in a rat model of hydrocephalus. JCI Insight. 2020. https://doi.org/10.1172/jci.insight. 137646.
60. O'hayon B, Drake J, Ossip M, Tuli S, Clarke M. Frontal and occipital horn ratio: a linear estimate of ventricular size for multiple imaging modalities in pediatric hydrocephalus. Pediatr Neurosurg. 1998;29(5):245-9.

61. Klarica M, Miše B, Vladić A, Radoš M, Orešković D. "Compensated hyperosmolarity" of cerebrospinal fluid and the development of hydrocephalus. Neuroscience. 2013;248:278-89.

62. Sørensen P, Gjerris A, Hammer M. Cerebrospinal fluid vasopressin in neurological and psychiatric disorders. J Neurol Neurosurg Psychiatry. 1985;48(1):50-7.

63. Borenstein-Levin L, Koren I, Kugelman A, Bader D, Toropine A, Riskin A. Post-hemorrhagic hydrocephalus and diabetes insipidus in preterm infants. J Pediatr Endocrinol Metab. 2014;27(11-12):1261-3.

64. Thakore P, Dunbar A, Lindsay E. Central diabetes insipidus: A rare complication of IVH in a very low birth weight preterm infant. J NeonatalPerinatal Med. 2019;12(1):103-7.

65. Van der Kaay DC, Van Heel WJ, Dudink J, van den Akker EL. Transient diabetes insipidus in a preterm neonate and the challenge of desmopressin dosing. J Pediatr Endocrinol Metab. 2014;27(7-8):769-71.

66. Shiel RE, Pinilla M, Mooney CT. Syndrome of inappropriate antidiuretic hormone secretion associated with congenital hydrocephalus in a dog J Am Anim Hosp Assoc. 2009;45(5):249-52.

67. Campos Y, Qiu X, Gomero E, Wakefield R, Horner L, Brutkowski W, et al. Alix-mediated assembly of the actomyosin-tight junction polarity complex preserves epithelial polarity and epithelial barrier. Nat Commun. 2016;7(1):1-15.

68. Guerra MM, Henzi R, Ortloff A, Lichtin N, Vío K, Jiménez AJ, et al. Cell junction pathology of neural stem cells is associated with ventricular zone disruption, hydrocephalus, and abnormal neurogenesis. J Neuropathol Exp Neurol. 2015;74(7):653-71.

69. de Laurentis C, Cristaldi P, Arighi A, Cavandoli C, Trezza A, Sganzerla $E P$, et al. Role of aquaporins in hydrocephalus: what do we know and where do we stand? A systematic review. J Neurol. 2020. https://doi. org/10.1007/s00415-020-10122-z.

70. Castañeyra-Ruiz L, González-Marrero I, Carmona-Calero EM, AbreuGonzalez P, Lecuona M, Brage L, et al. Cerebrospinal fluid levels of tumor necrosis factor alpha and aquaporin 1 in patients with mild cognitive impairment and idiopathic normal pressure hydrocephalus. Clin Neurol Neurosurg. 2016;146:76-81.

71. Ding Y, Zhang T, Wu G, McBride DW, Xu N, Klebe DW, et al. Astrogliosis inhibition attenuates hydrocephalus by increasing cerebrospinal fluid reabsorption through the glymphatic system after germinal matrix hemorrhage. Exp Neurol. 2019;320:113003.

72. Brinker T, Stopa E, Morrison J, Klinge P. A new look at cerebrospinal fluid circulation. Fluids Barriers CNS. 2014;11(1):1-16.

73. Oshio K, Watanabe H, Song Y, Verkman A, Manley GT. Reduced cerebrospinal fluid production and intracranial pressure in mice lacking choroid plexus water channel Aquaporin-1. FASEB J. 2005;19(1):76-8.

74. Papadopoulos MC, Verkman AS. Aquaporin water channels in the nervous system. Nat Rev Neurosci. 2013;14(4):265-77.

75. Hua C, Zhao G. Biomarkers in adult posthemorrhagic hydrocephalus. Int J Stroke. 2017;12(6):574-9.

76. Frosini M, Sesti C, Palmi M, Valoti M, Fusi F, Mantovani P, et al. Heatstress-induced hyperthermia alters CSF osmolality and composition in conscious rabbits. Am J Physiol Regul Integr Comp Physiol. 2000:279(6):R2095-103.

77. Kahle KT, Kulkarni AV, Limbrick DD Jr, Warf BC. Hydrocephalus in children. Lancet. 2016;387(10020):788-99.

78. Gram M, Sveinsdottir S, Cinthio M, Sveinsdottir K, Hansson SR, Mörgelin $M$, et al. Extracellular hemoglobin-mediator of inflammation and cell death in the choroid plexus following preterm intraventricular hemorrhage. J Neuroinflammation. 2014;11(1):1-15.

79. Thwaites GE, Macmullen-Price J, Chau TTH, Mai PP, Dung NT, Simmons $C P$, et al. Serial MRI to determine the effect of dexamethasone on the cerebral pathology of tuberculous meningitis: an observational study. Lancet Neurol. 2007;6(3):230-6.

80. Jiménez AJ, Domínguez-Pinos M-D, Guerra MM, Fernández-Llebrez P, Pérez-Fígares J-M. Structure and function of the ependymal barrier and diseases associated with ependyma disruption. Tissue barriers. 2014;2(1):e28426. 
81. Karimy JK, Duran D, Hu JK, Gavankar C, Gaillard JR, Bayri Y, et al. Cerebrospinal fluid hypersecretion in pediatric hydrocephalus. Neurosurg Focus. 2016;41(5):E10

82. Damkier HH, Brown PD, Praetorius J. Cerebrospinal fluid secretion by the choroid plexus. Physiol Rev. 2013;93(4):1847-92.

83. Speake T, Whitwell C, Kajita H, Majid A, Brown PD. Mechanisms of CSF secretion by the choroid plexus. Microsc Res Tech. 2001;52(1):49-59.

84. Damkier HH, Brown PD, Praetorius J. Epithelial pathways in choroid plexus electrolyte transport. Physiology. 2010;25(4):239-49.

85. Siesjö BK. The regulation of cerebrospinal fluid pH. Kidney Int. 1972;1(5):360-74.

86. Christensen HL, Barbuskaite D, Rojek A, Malte H, Christensen IB, Füchtbauer AC, et al. The choroid plexus sodium-bicarbonate cotransporter NBCe2 regulates mouse cerebrospinal fluid pH. J Physiol. 2018;596(19):4709-28.

87. Bueno D, Garcia-Fernandez J. Evolutionary development of embryonic cerebrospinal fluid composition and regulation: an open research field with implications for brain development and function. Fluids Barriers CNS. 2016;13(1):1-12.

88. Vong Kl, Ma TC, Li B, Leung TCN, Nong W, Ngai SM, et al. SOX9COL9A3-dependent regulation of choroid plexus epithelial polarity governs blood-cerebrospinal fluid barrier integrity. Proc Natl Acad Sci. 2021;118(6):e2009568118

89. Krishnamurthy S, Li J, Shen Y, Duncan TM, Jenrow KA, Haacke EM. Normal macromolecular clearance out of the ventricles is delayed in hydrocephalus. Brain Res. 2018;1678:337-55.

90. Gato A, Alonso Ml, Martín C, Carnicero E, Moro JA, De la Mano A, et al. Embryonic cerebrospinal fluid in brain development: neural progenitor control. Croat Med J. 2014;55(4):299-305

91. Alonso MI, Lamus F, Carnicero E, Moro JA, de la Mano A, Fernández JM, et al. Embryonic cerebrospinal fluid increases neurogenic activity in the brain ventricular-subventricular zone of adult mice. Front Neuroanat. 2017:11:124.

92. Gato Á, Moro J, Alonso MI, Bueno D, De La Mano A, Martin C. Embryonic cerebrospinal fluid regulates neuroepithelial survival, proliferation, and neurogenesis in chick embryos. Anat Record Part A Discov Mol Cell Evol Biol. 2005;284(1):475-84.

93. Kent AL, Wright IM, Abdel-Latif ME. Mortality and adverse neurologic outcomes are greater in preterm male infants. Pediatrics. 2012;129(1):124-31.

94. Shankaran S, Lin A, Maller-Kesselman J, Zhang H, O'Shea TM, Bada HS, et al. Maternal race, demography, and health care disparities impact risk for intraventricular hemorrhage in preterm neonates. J Pediatr. 2014;164(5):1005-11.e3.

95. Linder N, Haskin O, Levit O, Klinger G, Prince T, Naor N, et al. Risk factors for intraventricular hemorrhage in very low birth weight premature infants: a retrospective case-control study. Pediatrics. 2003;111(5):e590-5.

96. Vohr B, Allan WC, Scott DT, Katz KH, Schneider KC, Makuch RW, et al., editors. Early-onset intraventricular hemorrhage in preterm neonates: incidence of neurodevelopmental handicap. Seminars in perinatology; 1999: Elsevier.

97. Afsharkhas L, Khalessi N, Panah MK. Intraventricular hemorrhage in term neonates: sources, severity and outcome. Iran J Child Neurol. 2015;9(3):34.

\section{Publisher's Note}

Springer Nature remains neutral with regard to jurisdictional claims in published maps and institutional affiliations.

Ready to submit your research? Choose BMC and benefit from:

- fast, convenient online submission

- thorough peer review by experienced researchers in your field

- rapid publication on acceptance

- support for research data, including large and complex data types

- gold Open Access which fosters wider collaboration and increased citations

- maximum visibility for your research: over 100M website views per year

At BMC, research is always in progress.

Learn more biomedcentral.com/submissions 